\title{
Predictive Value for Malignancy of the Thyroid Nodule Macroscopically
}

\author{
Valor de Predição para Malignidade dos Aspectos Macroscópicos do \\ Nódulo Tireoidiano
}

\section{Rogério Aparecido Dedivitis*, Sergio Dias do Couto Netto**, Mario Augusto Ferrari de Castro ***, Elio Gilberto PfuetzenreiterJr.****, Carlos Eduardo Molinari Nardi*****, Emanuel Casotti Duque de Barbara $* * * * *$.}

\begin{abstract}
* Full Professor, Faculty of Medical Sciences University Center Lusíada UNILUS, Santos, Chief, Division of Surgery and the Division of Teaching Hospital Ana Costa, Santos, Chief of Head and Neck Surgery of the Brotherhood of Santa Casa da Misericordia Santos, Professor, Graduate Course in Health Sciences Complex Hospital Heliopolis, São Paulo.

** Ex-Resident of General Surgery, Hospital Ana Costa, Santos / SP.

*** Resident of the Head and Neck Surgery, Hospital Ana Costa, Santos, Master Course Graduate Health Sciences University Center Lusíada UNILUS, Santos, Professor, Department of Surgery, Faculty of Medical Sciences University Center Lusíada UNILUS , Santos.

***** By Master Course Graduate Health Sciences, Heliopolis Hospital Complex HOSPHEL, São Paulo, Professor, Department of Surgery, Faculty of Medical Sciences University Center Lusíada UNILUS, Santos; Surgeon Assistant Surgery Service Head and Neck Surgery, Hospital Ana Costa and the Brotherhood of Santa Casa de Santos. ******* Resident in General Surgery, Hospital Ana Costa, Santos / SP.

******* Ex-Scholar, School of Medical Sciences of Santos, the Foundation Lusíada UNILUS under internship at Hospital Ana Costa, Santos / SP.
\end{abstract}

Institution: Department of Head and Neck Surgery, Faculty of Medical Sciences Foundation Lusíada; Service Head and Neck Surgery, Hospital Ana Costa, Santos, and Surgery Department of Head and Neck Brotherhood of Santa Casa de Santos. Santos / SP - Brazil.

Mail Address: Rogerio A. Dedivitis - Rua Dr. Olinto Rodrigues Dantas, 343 set in 1992 - Santos / SP - Brazil - Zip code: 11050-220 - Telephone: (+55 13) 3223-5550 / 3221-1514 - E-mail: dedivitis.hns@uol.com.br

Article received in March 14, 2010. Article accepted in May 1, 2010.

\section{SUMMARY}

Introduction:

Objective:

Methods:

Results:

Conclusion:

Keywords:

\section{RESUMO}

Introdução:

Objetivo:

Método:

Resultados:

Conclusão:

Palavras-chave:
The fine needle aspiration (FNA) is a method of high accuracy in the preoperative diagnosis of thyroid nodules, but the "follicular" remains a factor of failure. Furthermore, the usefulness of intraoperative examination of freezing is controversial. Macroscopic aspects of thyroid nodules may increase the diagnostic accuracy of preoperative and intraoperative FNA biopsy and freezing.

To evaluate the macroscopic aspects of the surgical specimen in the decision facing the nodular disease of thyroid gland.

During 2007, 85 patients underwent surgical treatment for thyroid nodular diseases were evaluated by prospective and macroscopic aspects of 125 nodules were compared with histopathological findings. We found that the pattern of recent growth, the presence of adhesions of the thyroid, absence of hemorrhage, necrosis and poor demarcation of the nodule had statistical significance in the outcome of malignant disease.

Pattern of growth, thyroid adhesions, necrosis and poor demarcation of the nodule are predictors of malignancy, while the presence of hemorrhage is a protective factor.

thyroid neoplasms, thyroidectomy, sensitivity and specificity, biopsy, needle, frozen sections.

A punção aspirativa por agulha fina (PAAF) é um método de alta acurácia no diagnóstico pré-operatório dos nódulos tireoidianos, mas o "padrão folicular" segue sendo um fator de falha. Por outro lado, a utilidade do exame intra-operatório de congelação é controversa. Aspectos macroscópicos dos nódulos tireoidianos podem aumentar a acurácia diagnóstica pré e intra-operatória da PAAF e a biópsia de congelação.

Avaliar os aspectos macroscópicos do espécime cirúrgico na tomada de decisão frente à doença nodular da glândula tireoide.

Durante 2007, 85 pacientes submetidos a tratamento cirúrgico por doença nodular tireoidiana foram avaliados por estudo prospectivo e os aspectos macroscópicos de 125 nódulos foram comparados aos achado histopatológicos.

Foi observado que o padrão de crescimento recente, a presença de aderências da tireoide, a ausência de hemorragia, a presença de necrose e a má delimitação do nódulo tiveram significado estatístico no resultado de doença maligna.

Padrão de crescimento, aderências da tireoide, necrose e a má delimitação do nódulo são fatores indicativos de malignidade, enquanto a presença de hemorragia é fator protetor.

neoplasias da glândula tireoide, tireoidectomia, sensibilidade e especificidade, biópsia por agulha, secções congeladas. 


\section{INTRODUCTION}

The fine needle aspiration (FNA) is a pre-surgical method of high accuracy in laboratory diagnosis of thyroid nodules in detecting cancer (1) and is still, however, the "follicular neoplasm" a dilemma (2). FNA guided by ultrasound (USG) performed by a radiologist with the cytopathologist spot shows superior results compared with puncture guided by manual palpation. Moreover, the value of intraoperative biopsy freezing still remains controversial as to its potential to help the surgeon to decide between doing the hemithyroidectomy or total thyroidectomy. The method potentially can avoid a second surgery to remove the contra-lateral lobe the surgical specimen revealed malignancy on histopathology embedded in paraffin, and in the evaluation of the macroscopic part and may thus avoid an unnecessary total thyroidectomy, which takes the patient to the use of permanent replacement of levothyroxine and increases the chance of injury and hypoparathyroidism of the recurrent laryngeal nerve (3).

Several studies have been performed, demonstrating the accuracy of frozen section examination (4). However, despite having been described in classic literature (5), macroscopy of thyroid nodules was used rarely as an object of study as an aid in determining the nature of the injury.

The aim of this study is to assess the value of the

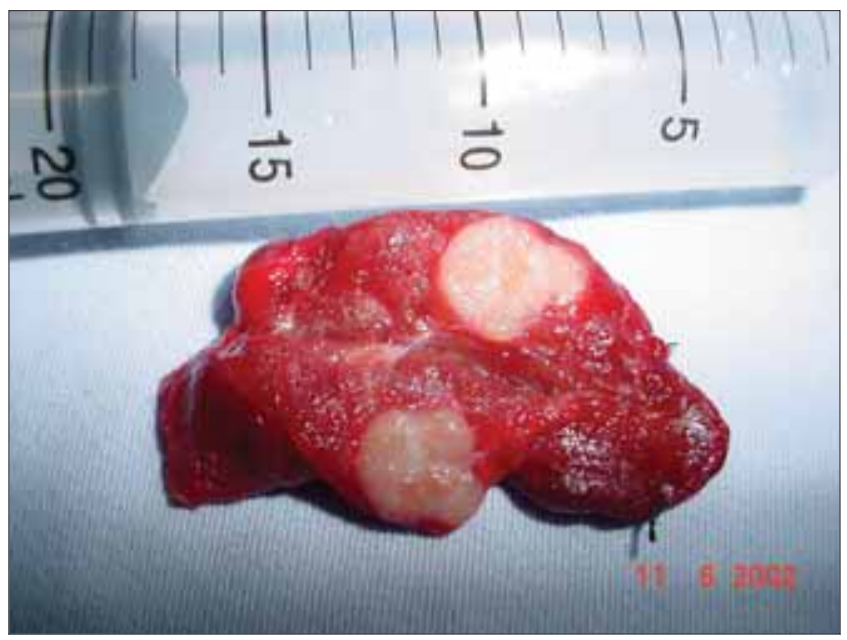

Figure 1. Surgical specimen showing solid nodule of whitish and homogeneous aspect, without hemorrhagic or necrotic foci with poorly defined margins, no capsular invasion extratireoidiana and firm consistency. The diagnosis was papillary carcinoma. macroscopic evaluation of the play in defining the extent of surgery before the disease nodular thyroid gland.

\section{METHOD}

This study was approved by the Ethics in Research of the Hospital Guilherme Álvaro, Santos, in July 2007. During the year 2007 in a prospective study, 85 patients were consecutively underwent thyroidectomy for nodular thyroid disease by the same surgical team. Of these patients, 74 (87\%) were female and 12 (13\%) were male. The age ranged 18-82 years, mean 49.9 years. Sixty-two patients had single nodules. Patients who had more than one nodule had the other nodes also studied.

All surgical specimens (Figures 1, 2, 3, 4), during surgery, immediately after its withdrawal, underwent surgical examination by the surgical team followed protocol, noting information on the size, nature (solid, cystic or cystic with solid component), capsule (complete or no, thickness and presence of invasion), definition, color (white, yellow, pink, brown, brown) and degenerative (hemorrhage, fibrosis, calcification, necrosis) of thyroid nodules.

The histopathological diagnosis of paraffin embedded material was available for each nodule studied. The macroscopic characteristics of the nodules were compared to the results of pathology.

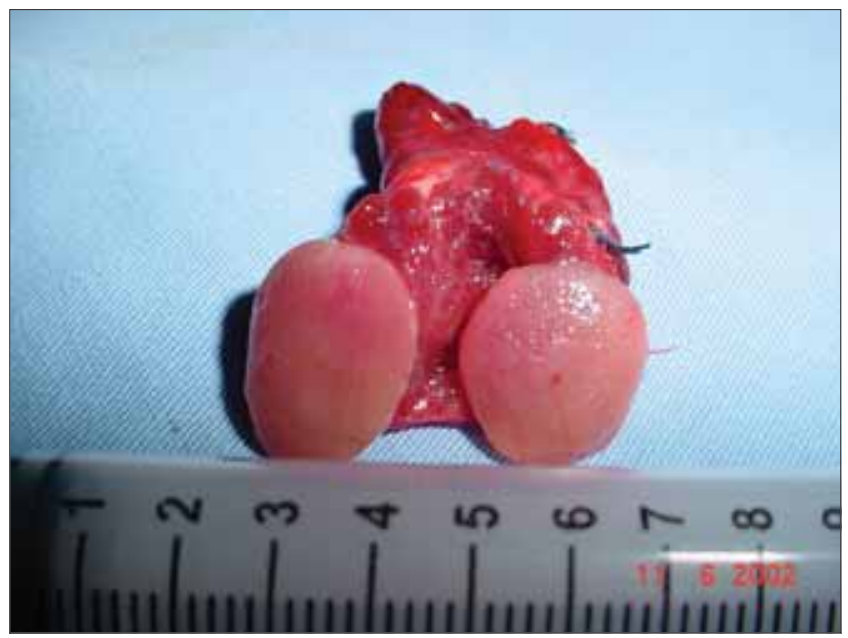

Figure 2. Surgical specimen showing solid nodule of homogeneous aspect and pinkish, without hemorrhagic or necrotic foci with well-defined margins, with thin capsule without invasion extratireoidiana and elastic consistency. Freezing and paraffin showed follicular neoplasm, follicular adenoma. 


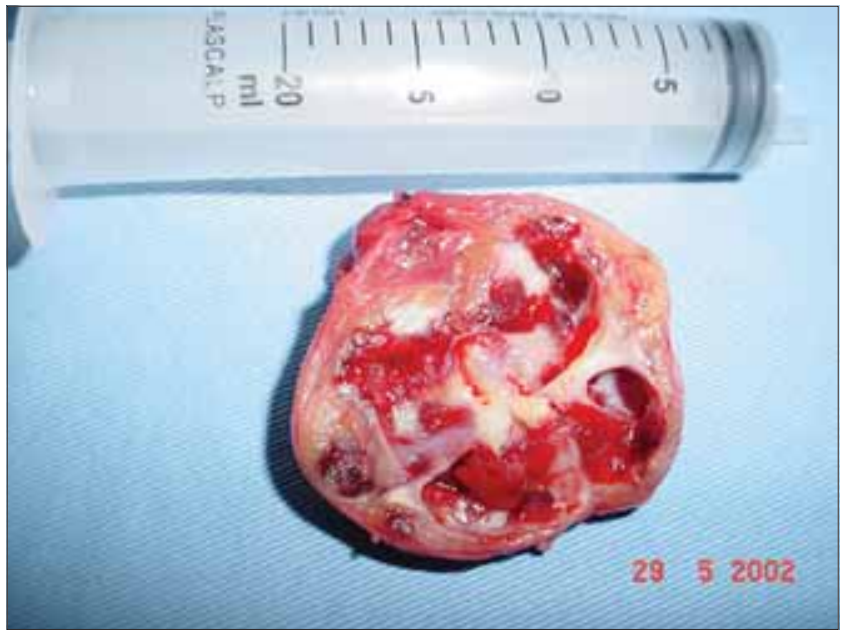

Figure 3. Surgical specimen with a solid nodule with a cystic component, vegetated, heterogeneous aspect and pinkish, yellowish, with areas of fibrosis, hemorrhagic foci with welldefined margins, thick capsule without invasion and extratireoidiana fibroelastic consistency. The diagnosis was goiter with cystic degeneration.

\section{RESULTS}

Table 1 shows the general characteristics of the lesions and capsules. The size of the nodules ranged from 0.5 to $12 \mathrm{~cm}$, with an average of $4.1 \mathrm{~cm}$. Ninety-three nodules showed complete capsule, while 29 had no capsule. The capsule was thin and had a regular basis in most cases. In two cases there was gross invasion of the capsule by tumor.

Table 2 shows the characteristics of nature, look to cut, texture, color and secondary characteristics (fibrosis, hemorrhage, calcification) of the nodules. Ninety-four nodules were solid in nature, most homogeneous and of soft consistency to the cut. The most characteristic secondary hemorrhage was found (55.2\%), followed by coarse calcifications (47.2\%) and fibrosis (37.6\%).

Table 3 shows as was the distribution of pathological findings in this study, $77.6 \%$ consisted of benign lesions, resulting in goiter. Of the 28 carcinoma cases, 23 were papillary carcinomas, accounting for $82.1 \%$ of cases of malignancy.

The comparison of macroscopic findings with the results of pathological studies show that the pattern of recent growth $(\mathrm{p}=0.002)$ and the presence of adhesions thyroid ( $p<0.001$ ), absence of bleeding ( $p<0.001$ ), presence of necrosis ( $p<0.001$ ), and poor delineation of nodule $(\mathrm{p}<0.001)$ had statistical significance in the outcome of malignant disease - Tables 4 and 5 .

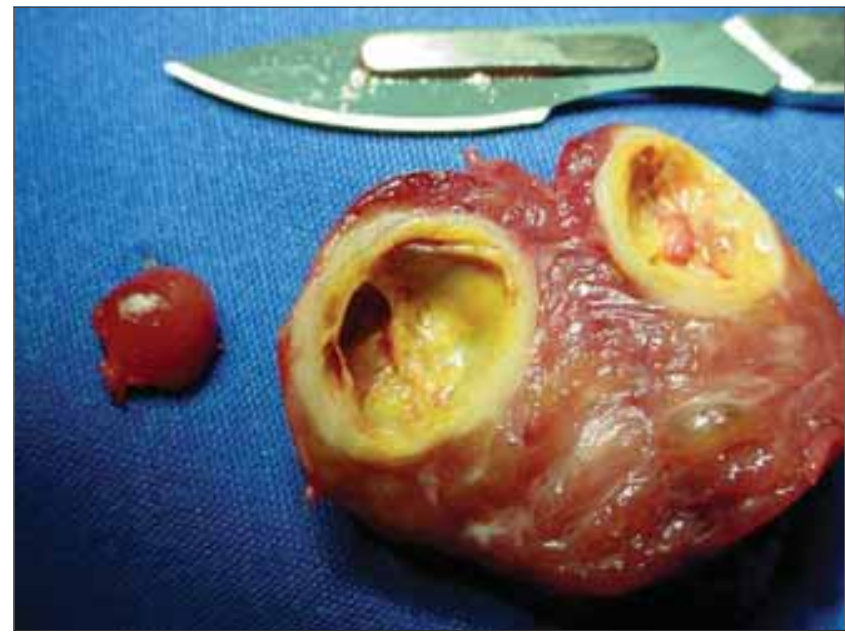

Figure 4. Surgical specimen showing solid nodule with a cystic component of homogeneous aspect and a yellowish, with areas of fibrosis, without hemorrhagic or necrotic foci, with well-defined margins, thick capsule without invasion extratireoidiana and fibro-elastic consistency. The diagnosis was goiter with cystic degeneration.

Table I. General characteristics of the nodules and capsules.

\begin{tabular}{llc}
\hline Variable & Categoryormeasures & $\mathrm{N}(\%)$ or measures \\
\hline Lesion & Single & $62(49.6)$ \\
& Multipleipsilateral & $1 \mid(8.8)$ \\
& Multiplecontralateral & $52(41.6)$ \\
Adhesion & 0 & $94(75.2)$ \\
& 1 & $31(24.8)$ \\
Size $(\mathrm{cm})$ & $\mathrm{n}$ & 125 \\
& Variation & 0.5 to I2 \\
& Median & 4 \\
& Average(SD) & $4.1(2.5)$ \\
Capsule & No & $29(23.2)$ \\
& Incomplete & $3(2.4)$ \\
& Complete & $93(74.4)$ \\
Thickness & Thin & $94(75.2)$ \\
& Thick & $31(24.8)$ \\
Form & Regular & $112(89.6)$ \\
& Irregular & $13(10.4)$ \\
Capsule invasion & No & $123(98.4)$ \\
& Yes & $2(1.6)$ \\
Limits & Well-defined & $107(85.6)$ \\
& baddefined & $18(14.4)$ \\
\hline
\end{tabular}

\section{DISCUSSION}

It was shown that the frozen biopsy (BC) has sensitivity, specificity, predictive values for positive 
Table 2. Characteristics of thyroid nodules.

\begin{tabular}{|c|c|c|}
\hline Variable & Categoryor measures & $\mathrm{N}(\%)$ or measures \\
\hline Nature & $\begin{array}{l}\text { Solid } \\
\text { Solid-componentcystic } \\
\text { Cystwith vegetation } \\
\text { Cyst }\end{array}$ & $\begin{array}{c}94(75.2) \\
27(21.6) \\
3(2.4) \\
1(0.8)\end{array}$ \\
\hline Cut & $\begin{array}{l}\text { homogeneous } \\
\text { Internal Lobulations } \\
\text { Heterogeneous }\end{array}$ & $\begin{array}{l}78(62.4) \\
12(9.6) \\
35(28.0)\end{array}$ \\
\hline Consistency & $\begin{array}{l}\text { Firm } \\
\text { Fibro-elastic } \\
\text { Granular } \\
\text { Soft } \\
\text { Crispy } \\
\text { Stony } \\
\text { Steady + Granular } \\
\text { Firm + Soft } \\
\text { Fibro-elastic + granular }\end{array}$ & $\begin{aligned} 24 & (19.2) \\
21 & (16.8) \\
41 & (32.8) \\
27 & (21.6) \\
0 & (0.0) \\
6 & (4.8) \\
2 & (1.6) \\
2 & (1.6) \\
2 & (1.6)\end{aligned}$ \\
\hline Coloring & $\begin{array}{l}\text { Bleached } \\
\text { Rosy } \\
\text { Yellow } \\
\text { Brown } \\
\text { Chestnut } \\
\text { Rosy + white } \\
\text { Yellowish + white } \\
\text { Rosy + yellow }\end{array}$ & $\begin{array}{c}12(9.6) \\
78(62.4) \\
13(10.4) \\
3(2.4) \\
14(11.2) \\
1(0.8) \\
3(2.4) \\
1(0.8)\end{array}$ \\
\hline Color & $\begin{array}{l}\text { Uniform } \\
\text { Heterogeneous }\end{array}$ & $\begin{array}{l}28(22.4) \\
97(77.6)\end{array}$ \\
\hline Bleeding & $\begin{array}{l}\text { No } \\
\text { Yes }\end{array}$ & $\begin{array}{l}56(44.8) \\
69(55.2)\end{array}$ \\
\hline Fibrosis & $\begin{array}{l}\text { No } \\
\text { Yes }\end{array}$ & $\begin{array}{l}78(62.4) \\
47(37.6)\end{array}$ \\
\hline Calcification & $\begin{array}{l}\text { No } \\
\text { Microcalcifications } \\
\text { Gross calcifications }\end{array}$ & $\begin{aligned} 60 & (48.0) \\
6 & (4.8) \\
59 & (47.2)\end{aligned}$ \\
\hline Necrosis & $\begin{array}{l}\text { No } \\
\text { Yes }\end{array}$ & $\begin{array}{l}\text { I| } 4 \text { (9I.2) } \\
\quad||(8.8)\end{array}$ \\
\hline Invasion & $\begin{array}{l}\text { No } \\
\text { Thyroid tissue } \\
\text { Extra-thyroidtissue } \\
\text { Thyroid + extra-thyroid }\end{array}$ & $\begin{array}{l}\text { I } 4(9 \mid .2) \\
5(4.0) \\
5(4,0) \\
\mid(0.8)\end{array}$ \\
\hline
\end{tabular}

Table 3. Distribution of pathological findings of thyroid nodules.

\begin{tabular}{llc}
\hline Variable & Category or measures & $\mathrm{N}(\%)$ or measures \\
\hline Anatomopathological & adenomatous goiter & $77(6 \mid .6)$ \\
& Follicularadenoma & $19(15.2)$ \\
& Papillary Ca & $23(18.4)$ \\
& Follicular Ca & $2(1.6)$ \\
Medullary Ca & $2(1.6)$ \\
Undifferentiated Ca & $1(0.8)$ \\
Chronicthyroiditis & $1(0.8)$ \\
\hline
\end{tabular}

and negative tests and global accuracy reaching respectively $69 \%, 100 \%, 100 \%, 91.5 \%$ and $77 \%$. Thus, evaluating the $\mathrm{BC}$, both specificity and positive predictive value of the test are high (4). This means that when the method of $\mathrm{BC}$ shows that this is cancer, such an interpretation is highly reliable. The results of "follicular" come with the recommendation by the pathologist, to await the outcome of the "paraffin," because the criteria were not found necessary to close the diagnosis of malignancy, is not recommending total thyroidectomy systematically.

Although there are many studies evaluating the role of FS (4), studies on the macroscopic characteristics of thyroid nodules and their relation to the diagnosis PAs are rare. The main role of the macroscopic study would assist the medical team in deciding the extent of surgery in cases "doubtful."

Rosai et al. had described macroscopic characteristics of the various pathologies that affect the thyroid gland. Thus, characteristics such as invasion of thyroid parenchyma or structures extratireoidianas, few defined margins, presence of necrosis and small calcifications, and varying in color from yellow to brown and white are common characteristics of medullary carcinomas, and anaplastic carcinomas. In addition, papillary carcinomas may have, when sectioned, the sense of having small grains. These tumors usually have a hard consistency when compared to benign lesions. Benign lesions tend to have more pink color and uniform, with well-defined and often with a wellformed capsule. More benign lesions, could have a thicker capsule and the presence of degeneration and fibrosis, coarse calcifications, ossification, cyst formation and hemorrhage. Necrosis could only occur secondary to FNA (6).

Other authors have demonstrated that performance of FNAB could be related to the formation of hemorrhage or necrosis intraglandular, but without diagnostic significance. Furthermore, the formation of necrosis would not have a well-established mechanism (7).

Compared with our findings, we observed that nodules with recent growth, poorly defined, with invasion of thyroid tissue, necrosis intranodular and / or adherence to other thyroid structures (muscles) could be regarded with great suspicion of malignancy. Similarly, nodules with insidious growth, well-defined, with a cystic component, hemorrhage and / or fibrosis can be regarded with great suspicion of kindness. Among all these mentioned items, the presence or absence of thyroid adhesions, hemorrhage or necrosis and demarcation of the nodule (well or ill-defined) had statistical significance. 
Table 4. Macroscopic characteristics with respect to clinical characteristics, size and capsule of thyroid nodules compared with pathological results.

\begin{tabular}{|c|c|c|c|c|}
\hline Variable & Categoryormeasures & $\begin{array}{r}\text { Benign Disease } \\
\mathrm{N}(\%) / \mathrm{m}\end{array}$ & $\begin{array}{l}\text { Malignant } \\
\text { easures }\end{array}$ & $p$-value \\
\hline Gender & $\begin{array}{l}\text { Male } \\
\text { Female }\end{array}$ & $\begin{array}{c}5(38.5) \\
54(64.3)\end{array}$ & $\begin{array}{c}8(61.5) \\
30(35.7)\end{array}$ & $0.076(x)$ \\
\hline Recentgrowth & $\begin{array}{l}0 \\
1\end{array}$ & $\begin{array}{l}35(76.1) \\
15(4 \mid .7)\end{array}$ & $\begin{array}{ll}11 & (23.9) \\
21 & (58.3)\end{array}$ & $0,002(x)$ \\
\hline Lesion & $\begin{array}{l}\text { Single } \\
\text { Multiple ipsilateral } \\
\text { Multiple contralateral }\end{array}$ & $\begin{array}{c}28(48.3) \\
8(72.7) \\
38(77.5)\end{array}$ & $\begin{array}{c}30(51.7) \\
3(27.3) \\
11(22.5)\end{array}$ & NA \\
\hline Adhesion & $\begin{array}{l}0 \\
1\end{array}$ & $\begin{array}{l}64(72.7) \\
10(33.3)\end{array}$ & $\begin{array}{l}24(27.3) \\
20(66.7)\end{array}$ & $<0.001(x)$ \\
\hline Size $(\mathrm{cm})$ & $\begin{array}{l}\mathrm{n} \\
\text { variation } \\
\text { Median } \\
\text { Averge(SD) }\end{array}$ & $\begin{array}{c}74 \\
\text { I/dic } \\
4 \\
4.5(2.2)\end{array}$ & $\begin{array}{c}43 \\
0.5 \text { to } 12 \\
2 \\
3.5(2.8)\end{array}$ & $0.0050(\cup)$ \\
\hline Capsule & $\begin{array}{l}\text { No } \\
\text { Incomplete } \\
\text { Complete }\end{array}$ & $\begin{array}{c}7(26.9) \\
2(66.7) \\
55(73.0)\end{array}$ & $\begin{array}{l}19(73.1) \\
1(33.3) \\
24(27.0)\end{array}$ & NA \\
\hline Thickness & $\begin{array}{l}\text { Thin } \\
\text { Thick }\end{array}$ & $\begin{array}{l}46(67.6) \\
21(87.5)\end{array}$ & $\begin{array}{l}22(32.4) \\
3(12.5)\end{array}$ & $0.060(x)$ \\
\hline Form & $\begin{array}{l}\text { Regular } \\
\text { Irregular }\end{array}$ & $\begin{array}{c}61(73.5) \\
6(66.7)\end{array}$ & $\begin{array}{c}22(26.5) \\
3(33.3)\end{array}$ & $0.700(F)$ \\
\hline Capsule invasion & $\begin{array}{l}0 \\
1\end{array}$ & $\begin{array}{c}67(74.4) \\
0(0.0)\end{array}$ & $\begin{array}{l}23(25.6) \\
2(100.0)\end{array}$ & $0.072(F)$ \\
\hline Limits & $\begin{array}{l}\text { Well-defined } \\
\text { baddelimited }\end{array}$ & $\begin{array}{c}74(72.6) \\
0(0.0)\end{array}$ & $\begin{array}{l}28(27.4) \\
16(100.0)\end{array}$ & $<0.001(\mathrm{~F})$ \\
\hline
\end{tabular}

Table 5. Macroscopic features of nature, the cut surface and degeneration of the thyroid nodules compared with pathological results.

\begin{tabular}{|c|c|c|c|c|}
\hline Variable & Category & Benign Disease & $\begin{array}{l}\text { Malignant } \\
\text { N(\%) }\end{array}$ & $\begin{array}{l}\text { p-value } \\
\mathrm{N}(\%)\end{array}$ \\
\hline Nature & $\begin{array}{l}\text { Solid } \\
\text { Solid w / comp cystic } \\
\text { Cystw / vegetation } \\
\text { Cyst }\end{array}$ & $\begin{array}{l}51(57.3) \\
19(76.0) \\
3(100.0) \\
1(100.0)\end{array}$ & $\begin{array}{c}38(42.7) \\
6(24.0) \\
0(0.0) \\
0(0.0)\end{array}$ & NA \\
\hline Cut & $\begin{array}{l}\text { Homogeneous } \\
\text { Lobulationsinternal } \\
\text { Heterogeneous }\end{array}$ & $\begin{array}{c}41(56.2) \\
9(75.0) \\
24(72.7)\end{array}$ & $\begin{array}{l}32(43.8) \\
3(25.0) \\
9(27.3)\end{array}$ & NA \\
\hline Color & $\begin{array}{l}\text { Uniform } \\
\text { Heterogeneous }\end{array}$ & $\begin{array}{l}15(62.5) \\
55(61.1)\end{array}$ & $\begin{array}{c}9(37.5) \\
35(38.9)\end{array}$ & $0.901(x)$ \\
\hline Hemorrhage & $\begin{array}{l}0 \\
1\end{array}$ & $\begin{array}{l}22(43.1) \\
52(77.6)\end{array}$ & $\begin{array}{l}29(56.9) \\
15(22.4)\end{array}$ & $<0.001(x)$ \\
\hline Fibrosis & $\begin{array}{l}0 \\
1 \\
2\end{array}$ & $\begin{array}{l}40(54.0) \\
33(76.7) \\
\mid(100.0)\end{array}$ & $\begin{array}{c}34(46.0) \\
10(23.3) \\
0(0.0)\end{array}$ & NA \\
\hline Calcification & $\begin{array}{l}\text { No } \\
\text { Microcalcifications } \\
\text { Gross calcifications }\end{array}$ & $\begin{array}{l}29(52.7) \\
2(33.3) \\
43(75.4)\end{array}$ & $\begin{array}{c}26(47.3) \\
4(66.7) \\
14(24.6)\end{array}$ & NA \\
\hline Necrosis & $\begin{array}{l}0 \\
1\end{array}$ & $\begin{array}{c}74(69.2) \\
0(0.0)\end{array}$ & $\begin{array}{l}33(30.8) \\
11(100.0)\end{array}$ & $<0.001(\mathrm{~F})$ \\
\hline
\end{tabular}


The presence of invasion of tissues outside the thyroid, as well as a predictor of malignancy, histology may be related to more aggressive and less differentiated and may be considered a negative prognostic factor, with a higher rate of recurrence (5).

\section{CONCLUSION}

The macroscopic characteristics of thyroid nodules may help FNA and frozen biopsy in differentiating benign and malignant disease. Adhesions thyroid necrosis and poor demarcation of the nodule are predictors of malignancy. Moreover, the presence of hemorrhage is a protective factor.

\section{BibliOgRAPHICAL REFERENCES}

1. Mazeh H, Beglaibter N, Prus D, Ariel I, Freund HR. Cytohistologic correlation of thyroid nodules. Am J Surg. 2007, 194(2):161-3.

2. Stacul F, Bertolotto M, Zappetti R, Zanconati F, Cova MA.
The radiologist and the cytologist in diagnosing thyroid nodules: results of cooperation. Radiol Med (Torino). 2007, 112(4):597-602.

3. Shaha AR. Advances in the management of thyroid cancer. Int J Surg. 2005, 3(3):213-20.

4. Almeida JP, Couto Netto SD, Rocha RP, Pfuetzenreiter Jr EG, Dedivitis RA. The role of intraoperative frozen sections for thyroid nodules. Braz J Otorhinolaryngol. 2009, 75(2):256-60.

5. Tscholl-Ducommun J, Hedinger CE. Papillary thyroid carcinomas. Morphology and prognosis. Virchows Arch A Pathol Anat Histol. 1982, 396(1):19-39.

6. Rosai J, Cargangiu ML, Delellis LA. Tumors of the thyroid gland. In: Rosai J, Cargangiu ML, Delellis LA. Atlas of tumor pathology. Washington: Armed Forces Institute of Pathology; 1992.

7. Kini SR. Post-fine-needle biopsy infarction of thyroid neoplasms: a review of 28 cases. Diagn Cytopathol. 1996, 15(3):211-20. 